\title{
Philosophy of Being - The Franciscan Mission in Yuan-, late Ming-, and Early Qing- Dynasty China as an Example of Cultural and Intercultural Approaches
}

\author{
Sigrid Steinschaden \\ Projects: Mongolia, China \\ sigrid.steinschaden@gmail.com
}

\begin{abstract}
In this paper a first overview to an approach of the intercultural development of an individual self, working and living abroad is given. The main focus is set on the Franciscan mission in Mongolia and China by developing an idea of specific turning points in the modes of experiences that are part of the descriptions in itineraries, relations of journeys and stays, from Yuan Dyansty on. The basic idea is that with the founding of the order as missionary order very specific attitudes were required and developed that are strongly related to the individual personality and its ways of dealing with rules from the order, its authorities and the influence given by people and experiences abroad. Conclusions of this anachronic and diachronic development of Franciscanism are intended to become compared to 'Corporate Identities' set in an international environment of global acting companies working in China in the culture-philosophical field.

Index Terms - Franciscan Mission, Yuan Dynasty, Ming and Qing Dynasty, Intercultural Aspects
\end{abstract}

\section{Introduction}

One of the topics related to China that cause my special interest is the Franciscan order and its missionary work with a specific focus on the self-consciousness as friar, missionary and individual who deals in a very different culture from the one originating from. This means to me that even though a monk is much more defined by philosophical terms by corporate rules and policies, such as official regulations of the order that take great influence on individual behaviours of do's and don'ts in addition to theological knowledge that always is interlinked philosophical issue-dealing with different approaches, ideas, opinions, consequences, too, and being the clergyman furthermore obedient to a quite strict monastic life that combines in some ways work, leisure time, individual time, time spent in groups by following different activities, some parallels to contemporary western work environments dealing with Asia in general, and China in particular can be made.

And exactly this is another point of interest as intercultural management is more and more including into its discussion the psychological issues of working and living abroad by preparing and accompanying the individual in different stages of dealing with the other, often up to the repatriation that can be considered a massive turning-point as the individual might have changed in some ways due to the inter-relation with other cultures and mentalities.

There is an ongoing discussion of globalisation versus intercultural exchange, something that in very particular inputs makes me come back to the Franciscan friars who themselves were confronted with this evident difficulty of which priorities should be set in order to deal with the other and make the other 'buy a product' that in the case of missionaries even is something manually not graspable.

Their product should reach the souls, only, creating emotions towards the philosophicsystem of 'God' and 'Church' in general after having intellectually comprehended

the, let me call it 'construction under the surface'. Additionally faith as inner awareness and expression interfuses consciously with the psyche by declaring habits of self-conduct, dealing with the other, and furthermore accepting to be guided by an invisible force called 'God' who was considered to be very different from the various'forces in Heaven' the Chinese felt dependent of.

Many scientists, very often historians and theologians, have dealt with this question of instruction and evidently visible expression of faith by intermingling cultures, for China especially in the relevant discussion of 'accommodation or adaptation', that can be seen in its controversy as a discussion of 'globalisation', which corresponds to the strictly considered adherence to pure "western Catholicism" defended by the Franciscans versus 'intercultural exchange" propagated by the Jesuits by including national Chinese characteristics of greater importance consciously into a set and categorized system in order to make it run more efficiently by giving to it a greater practical convenience, requiring both sides to learn to adapt to each other.

Even if one changes perspectives, times, and more important culture defining the desire or need of certain instruction, one can see that those two ideas still interfere with each other.

Often it seems that, probably due to the always stronger ties between the East and the West in many fields of human activities, a sense of exploration has risen that gives somehow the energising feeling of being the first to experience the East. And exactly with this observation the idea came up to search for historic lines in dealing with the other culture under changing preconditions and environmental circumstances of all sorts, whereas I would

set the limits of the changeable preconditions in terms of the professional being to a set of changes in leadership instead of basic and unchangeable rules of corporate dealing.

Countries, such as China that want to develop consciously within a greater variety of cultures do not only need to 
compare those cultures and identify strengths and weaknesses of systems, but need to identify a strategically clear, obvious and well communicated new and creative way that fits to the own national, and therefore as well cultural needs. This generally speaking does not make international exchange more difficult, it even facilitates ex- and interchange in specific terms as already known, and therefore recognisable concepts open new perspectives due to an unknown and newly introduced 'fresh' element that causes a kind of curiosity and makes old concepts to be reconsidered much faster than it would be done without this consciously set national distinctive mark.

A similar situation could be identified in the past by using exactly the opposite approach which meant for the Franciscans not to change their concepts but to introduce and put them on the culture dealing with. And exactly this approach finally led to the same result of understanding and accepting the necessity of learning from the other culture by exchanging and developing cultures jointly in inter- changeable needs and concepts. At the beginning it happened more or less by learning by doing (struggles included) that the necessity of a more conscious approach was accepted but with the time more and more strategies were subliminary developed.

In order to be able to get a more precise greater picture of the interacting and intercultural development in historic lines it is necessary to work on the main sources under linguistic points of view related to cognition, psychology, anthropolgy and ethnology.

Let me therefore give in the next part some few selected examples of developing a being in China, again originating in the Franciscan missionary being and abstracting it into a daily approach that needs to be just touched at the moment.

\section{Franciscan Expressions of Missionary Being}

In the first instance I was thinking of dealing with selected examples of the late Ming- and Early Qing-Dynasty, only. I decided not to do so as the Franciscan mission towards Asia in the 13th and 14th century does have the advantage of being very close to the foundation of the order and therefore to the person of St. Francis, too.

Any direct comparison of the missionary reports and specific topics treated might give, even though still being a very generalised overview, a more precise picture of a kind of Franciscan being in China. We will see that under certain circumstances there had much more direct and symbolic referrals to the Christian roots in general and to the specific linkages of Christ as example for St. Francis been made during the Early Qing-Dynasty than before.

The Franciscan order has its advantage in the fact of defining itself already as reason for the foundation as an order focusing on mission. This advantage might be its weakest point when it comes to practice and therefore situations that cannot have been thought of from the very beginning on as the concept of the order was reflected in religious and cultural terms of a Christianity that needed to mission in a Muslim environment, and may expand its area of dealing to further continents and cultures. Anybody being attracted by the order and entering into it might have had to develop an always deeper going concept of self-awareness as religious being and cultural awareness of the other in order to make mission work. Exactly such intercultural concepts related to oneself usually are not frankly reported and discussed in the official documents such as reports, letters, statements given to authorities who were located more or less far of the site of mission being reported from. It is a kind of personal development that for sure every single missionary has undergone by dealing with the other, and, as being monks, have reflected about in times of contemplation or preparation of divine services.

What exactly is it the Franciscan monk needs to have in order to be ready for the mission? St. Francis has set certain rules that, as the documents give proof of, changed within the centuries according to needs and a pool of people available for the mission, but nevertheless there are set categories that among other things characterise the personality thought of being most appropriate for being sent abroad. Such main characteristics are the following and can be divided into three categories such as firstly preconditions a later missionary needs to fulfill, secondly general aspects that need to be considered during a missionary travel concerning the individual in psychological and in administrative terms, and thirdly missionary and theological work during the journey and at the final destination of themission.

Let me focus on ideas related strictly to therequirements of the individual as written in the rules of the order ${ }^{[1] ;[2]}$ :

* the vocation is necessarily part of a divine inspiration

(BReg XII, 1);

* readiness to give up the 'stabilitas loci' in order to travel the world (NbReg XVII, 5);

* allowance for mission should be given by the provincial minister after having examined thequalification of the applicant (BReg, XII, 2-3; NbReg XVI, 3-4);

* readiness for martyrdom (NbReg XVI, 11);

* on order of the Pope it is strictly forbidden to leave the order (NbReg II, 10; BReg II, 12-13);

* quarrels and other verbal arguments should be avoided (NbReg XI, 1-2; BReg III, 11);

* one should be mild, peaceable, gentle and humble, and should furthermore talk with everybody ina nice way

(NbReg XI, 9; BReg III, 11-12);

* the friars should avoid and keep themselves distant from pride, thirst for glory, jealousy andgreediness as well as from worries and pushing activities

(NbReg XVII, 6-9; BReg X, 7);

* who is not familiar with sciences should not try to study them (BReg X, 8);

* the friars should trust each other and tell the others of any difficulties (BReg VI, 8).

One can see that on the one hand a very steady personality was required in terms of religious faith, on the

\footnotetext{
${ }^{1}$ BReg (2001, p. 162 - 177)

${ }^{2}$ NbReg (2001, p. 177 - 204)
} 
other hand a very flexible, adaptable, open-minded, trusting to and quickly thinking attitude was appreciated when dealing with others.

At the beginning of the mission, little earlier than YuanDynasty with its capital Khanbaliq (Beijing) was established, the focus was laid on getting to know and understanding at least partly the other culture, in this case the Mongolian one. The reports of the time I am thinking of were written by the Franciscan friars John of Plano Carpini and William of Rubruck, and consist mainly in the description of what they had seen and what kind of background information they had gained. One can say that it was their duty to do so as their travels were just a kind ofanswer to the Mongolian invasion into European territories in 1241 and needed to provide this kind of information on special request of Pope Innocent IV and his allied kings. It was via those first contacts in Mongolian main territories that the links to the Mongolian rulers could be strengthened and transferred to Chinese main territories. Of course the picture gained, still was very much influenced by the rulers ${ }^{6}$ culture and just found a kind of liberation and independence by those missionaries who hadtraveled the country from South to North having arrived by sea via India.

The topics of dealing for sure relate to the literary form chosen, that is either a relation or a letter.

The letters, and it does not matter by whom they had been written, focused much more on the missionary work such as translations of texts into local language, building of churches, relationship to the emperor and his officials as well as financial issues whereas any relation has given a kind of insight into personal approaches towards and difficulties with the unknown others.

There is a first expression of individual fascination of Chinese cultural specifics by interacting with ordinary Chinese people, here with a landlord somewhere 18 days far from Fuzhou, for the first time in the relation of Odoric of Pordenone who left Europe for China around 1317. In this case he chose the form of direct speech, even though just for very short, in comparison to indirect referrals of what he had heard and therefore gave the landlord a voice of pride of the own Chinese culture to the readers of the relation. What did the landlord say? He just invited Odoric to join him for fishing and see how good fishes were caught by saying: 'Si tus vi bene piscari videre, veni mecum ${ }^{6}{ }^{[3]}$. The cultural specific is lying in this case on the tradition of cormoran fishing that was being mentioned for the first time by a Franciscan missionary. This very short episode is completed by the remark given again in direct speech of Odoric that he himself ate of the fish: 'Ego autem de illis piscibus manducavi ${ }^{[4]}$.

Still today daily needs such as eating are topics of getting easily into contact with locals as it is a common interest that refers to individual preferences of taste and learning about other ways of dealing with things, in this case with food and its origin, or production .

\footnotetext{
${ }^{3}$ Odoric XXII, 3, (1929, p. 462)

${ }^{4}$ ibid., (1929, p. 463)
}

Another Chinese topic introduced by Odoric was the Buddhist monastery. This kind of topic just showed up in relations as they gave retrospect impressions of the one having returned to Europe ${ }^{[5]}$. One city of interest was Zaitun where the Franciscan mission was located, too. He mentioned the approximate number of monks by 3,000 and the 11,000 Buddha statues that he of course did still call idols. He described furthermore the tradition of oblation, something he had been eyewitness of ${ }^{[6]}$.

A picture related to locals was provided with the description of an encounter that possibly took place in the monastery lin yin si at the West Lake at Hangzhou ${ }^{[7]}$. In this episode he got the concept of reincarnation explained by a local who had converted after he had been introduced to Christianity by four co-friars of Odoric. Odoric underlined somehow the idea of cultural exchange as this was a special moment of retro verse fascination and curiosity of the other that needed necessarily brought to the knowledge of the European reader. Even though one can compare this episode only in some aspects with religious impressions of Franciscans who had travelled Mongolia earlier on, one can see that the distance kept in the described personal dealing in the situation and the verbal manifestation are already less visible and desired, even though it is still implicated that Odoric was strong enough to stay firm and convinced in his own culturereligious background. He was not an observer, only, but an inter actor with people of various social backgrounds.

Again foreign religion and / or philosophies are something one should get to know in as many details as possible as it widens the horizon at least of contextual thinking and understanding approaches as well as attitudes mainly expressed in specific life-styles and habits that show tendencies of spiritual being, and therefore of the self as identification and manifestation. It is up to the individual whether and in which context to let the foreign religion or philosophy become part of oneself.

In the late Ming-Dynasty there was for the first time a relation, written in 1592 by John Baptist Lucarelli of Pisauro available that based only on direct speech. In this case the direct speech was used as a method of introducing the foreign culture to people who were defined as being'pilgrim', 'infidel', 'translator', 'judge', 'lay-brother', 'parson', 'chaldean bishop ${ }^{[8]}$.

I would like to pick out a discussion started by John Baptist Lucarelli that connects us once again to the identification of being a religious individual in an intercultural situation and to the identification hinted at earlier due to political circumstances encountered during Qing Dynasty, and already playing some role in the discussion focusing on at the moment.

Here two concepts are brought together: one is the identification by articles of clothing, the other one is the concept of regulations of stay abroad. The person bringing this

\footnotetext{
${ }^{5}$ M. Münkler (2000, p.89)

${ }^{6}$ Odoric XXI, $1 \& 2$ (1929, p. 460f.)

${ }^{7}$ F.Reichert(1987,p.140,Fn5)

${ }^{8}$ Ioh. Bapt. Lucarelli de Pisauro (1933)
} 
up is an 'infidel', a Chinese local who wanted to learn about the reason of the coming oft he friars. He hinted at the fact that all those who did not wear 'the large hat' (as sign of erudition) were not allowed to enter China and exchange ideas with the Chinese.

He even knew details of punishments for those who bound round a belt to the habit. The punishments started from perpetual prison to death penalty ${ }^{[9]}$. Of course the Franciscan friars knew exactly about the risk and the law preventing them from entering China but nevertheless they gave it a try, exactly because they could be not only identified as foreigners but as missionaries who had to fulfill a mandate. The Franciscans have chosen an obvious and easily identificable, because uniform expression of being but according to those hints given by the 'infidel' on conformity that allowed at least in its apparition the entry to China, one first step could have been a change in details by adapting to local preferences and positive connotations, just as the Jesuits used to do in terms of their mission.

Attribuitions can still be made nowadays by styles and clothings, and even if the consequences are very different from what the clergymen experienced, a kind of visible mindset and group specific might help to decide about the fitting to each other and help to identify some concerns of staying abroad.

The last reference ${ }^{[10]}$ I would like to make is a situation described quite similar to the one before with just one difference, that was the general prohibition of entering the country independent of appearance. One can see that in the Early Qing-Dynasty a new way of identification showedup that might be considered as symbol reference of the catholic faith itself to an unsatisfying situation caused by politics. Due to revolutions lead by some provinces whose rulers had unified under Wu Sangui against emperor Kangxi it was not possible to enter the country again and head north-eastwards towards Shandong province where one of the main Franciscan missions was located. It was exactly $\mathrm{Wu}$ Sangui who was one of the most important contact persons of the missionaries and who gave them every support possible to lead a spiritual life and to win new souls for the catholic faith in Canton. Nevertheless the situation of lacking liberty of movement lead to a phenomenon of comparing the frustrating situation itself to well known Christian stories by using very deep connotations and symbols such as 'Lucifer', Pontius Pilatus', 'desert', "wolves' towards the other in direct contrast to 'pastors', 'Christ Redemptor', "vineyards that were needed to be cultivated', 'lambs' as explanation of the own situation. It was a kind of struggle of opposites that came up as on the one hand the desire to move in the country was a very strong force and on the other hand the faced restrictions interpreted as a sign of significance that only could be solved by God as each single moment of struggle was bringing the whole mission forward at the right moment. For sure it was not only a struggle with the situation, it was as well a permanently struggle brought up in written documents with the budgeting if kept for too long from

\footnotetext{
${ }^{9}$ ibid. (1933, p. 53f.)

${ }^{10}$ Bonav. Ibanez (1936)
}

a more nationwide activity, but a very valuable time that lead to further analysis of how to deal with the other and what aspects one should focus on in order to reach the main aim: inland China.

The same often is true nowadays when encountered difficulties combined with the strong will to reach ones aims are discussed with a view on the foreign other and strengthening the own identity by defining oneselves mission, be it the product, the inner drive, even the financial situation that is a quite necessary part of the play.

\section{Summary}

It was possible to give just a very short insight into what could be considered a philosophy of being to the Franciscans by dealing with the Chinese other. As a first result one can say that changes within the historicdevelopment and establishment of the Franciscan order in China can be recognized.

That is part of a more and more self-aware and selfmotivated understanding of feeling the personal need of dealing in and with China and learning to understand relations on various levels such as political, geographical, inter-personal and social, spiritual, habitual.

Of course the more details and examples one can provide in its analysis the more the concepts of being can be interlinked and abstracted to a more general Franciscan philosophy of being in China.

Nevertheless I decided to see this paper as a first approach to get into this intercultural discussion of historic events of a specific group compared to a at the moment very generally and roughly hinted at nowadays situation that I could strive at the moment only as part of intercultural learning.

\section{References}

[1] St. Francis of Assissi. Regula bullata. [RegB] In Hardick, L. \& Grau, E. (eds.) "Die Schriften des heiligen Franziskus von Assissi. Kevelaer: Butzon \& Bercker, 2001, p. 162-177.

[2] St. Francis of Assissi. Regula non bullata. [NbReg] In Hardick, L. \& Grau, E. (eds.) "Die Schriften des heiligen Franziskus von Assissi. Kevelaer: Butzon \& Bercker, 2001 p. 177-204

[3] Odoric de Pordenone / Fr. Odoricus de Portu Naonis: Relatio. In: Sinica Franciscana I (ed.: P. Anastasius van den Wyngaert), Firenze: Quaracchi, 1929, p. 413-495.

[4] Münkler, Marina: Erfahrung des Fremden. Die Beschreibung Ostasiens in den Augenzeugenberichten des 13. und 14. Jahrhunderts. Diss. Berlin, 1997/98. Berlin: Akademie Verlag, 2000.

[5] Odorico de Pordenone: Die Reise des seligen Odorich von Pordenone nach Indien und China (1314/18-1330). (ed.: Folker Reichert). Heidelberg: Manutius, 1987.

[6] Iohannes Baptista Lucarelli de Pisauro: Viaggio dell‘ Indie. In: Sinica Franciscana II (ed.: P. Anastasius van den Wyngaert), Firenze: Quaracchi, 1933, p. 12-92.

[7] Bonaventura Ibanez: Epistolae et Relationes. In: Sinica Franciscana III (ed.: P. Anastasius van den Wyngaert), Firenze: Quaracchi, 1936, p. 19329. 